\title{
The Moluccas' Surviving Aristocracy in Indonesian Politics: Fragmentation and Land-based Political Support
}

\author{
Bayu Dardias Kurniadi ${ }^{1}$
}

Received: 23 July 2019 | Accepted: 23 December 2020 | Published: 30 December 2020

\begin{abstract}
The article demonstrates how the Sultanate of Ternate in the Moluccas has survived in post-authoritarian Indonesian politics by analysing the political performances of the Sultan of Ternate and his immediate family members. The success of Sultan Mudaffar Syah in the political arena has contextualised the literature on land-based political economy, something that has largely been neglected. Combining in-depth interviews, observations, and document study, I argue that the Sultan's political achievements were the result of his transforming Ternate's coastal aristocracy into a land-based one, sidestepping the Basic Agrarian Law (BAL) of 1960 by transferring land management and ownership to indigenous communities while still maintaining economic control. However, his wife and children have failed politically, not only because they are not part of the traditional aristocratic structure (and thus have no control over land) but also because of internal fragmentation.
\end{abstract}

Keywords: Moluccan aristocracy, land politics, sultan

\section{Introduction}

In his famous 'King's Dilemma', Samuel Huntington (1968) argued that the integration of monarchies into modern institutions leaves monarchs with an unfavourable dilemma: promoting reform would eventually result in challenges from reformist cadres, while delaying reform would result in popular protests. There is no place for monarchs in modern political architecture, which allows them to 'rule, but not reign' by limiting them to symbolic and traditional activities.
However, recent scholars have challenged Huntington's argument. Corbett, Veenendaal, and Ugyel (2016) show that monarchies in smaller states have been able to persevere and maintain political power. Based on a review of approximately twenty absolute or semiabsolute monarchical regimes in three small states (Tonga, Bhutan, and Liechtenstein), they argue that the endurance of monarchical power is inversely correlated with state size. First, small states tend to lack revolutions,

\footnotetext{
${ }^{1}$ Bayu Dardias Kurniadi is a PhD Candidate at the Department of Political and Social Change, Australian National University, Canberra. His email is bayu.dardias@anu.edu.au.
} 
thereby creating 'institutional fidelity' that helps monarchs to survive. Second, small states tend to have political systems that are 'personalised' to the monarch (rather than dispersed amongst political institutions). In such states, important political figures have multiple social, political, economic, and religious roles.

This article neither neglects nor accepts the above theories. It proposes a new argument regarding surviving aristocracies in electoral politics. Owing to low levels of institutionalisation and high levels of fragmentation, Indonesia's aristocracies and traditional institutionsunlike monarchies, which are dominated by one king-exist at the sub-national level (mostly at the district and sub-district level). Since 1998, aristocrats have tried (with various results) to compete in electoral arenas at national, provincial, and local levels. I argue that their success has depended on their ability to control land, as an economic resource, and to maintain cohesive internal relations. This will be shown using the example of the Sultanate of Ternate, which Sultan Mudaffar Syah transformed from a coastal aristocracy into a land-based aristocracy to sustain his political power. His political support came predominantly came from traditional areas, where land is under his direct control. However, such control cannot be genealogically transferred to his children and wife, as they are not part of the coastal sultanate structure. Lacking the capacity to maintain internal cohesiveness, his family has failed to achieve its political agenda. This finding fills important gaps in the theoretical debate on the political economy, which has largely ignored the importance of land in Indonesian politics.

I will present my argument chronologically, starting with the colonial period but emphasising post-authoritarian Indonesia. To achieve an understanding of local politics in Ternate, I will overview the role of land politics in Indonesia, as well as the political background of Ternate and the formation of the North Maluku Province (where ethnic competition has become a feature of local politics). I will then depict the fragmentation within the royal family, as revealed by members' political party affiliations and trajectories in post-Suharto politics. The next section will lay out this article's argument regarding land-based political transformations, as shown in the political performance of the Sultan and his immediate family members, who have received significant support from areas where the Sultan maintains control of land. I will then conclude this article with a reflective summary of the findings.

To begin, Ternate, an island located in the northern part of the Moluccas, has long been known as the home of four sultanates: Ternate, Tidore, Bacan, and Jailolo (Fala Raha) (Amal, 2010, p. 7). Historically, the strongest and the most influential sultanate in north Maluku has been the Sultanate of Ternate (Hanna \& Alwi, 1990). Its palace is located on Ternate Island $\left(37.23 \mathrm{~km}^{2}\right)$, which is dominated by the Gamalama stratovolcano; 56 of 77 villages are in coastal areas, and no settlement is located more than 500 metres from the sea (BPS Ternate, 2014, p. 9).

Early European explorers and merchants first travelled to the Moluccas for spices, especially nutmeg, pepper, and clove. Trade led to colonisation, first by the Portuguese, then by the Spanish and the Dutch (Burnet, 2011). When the price of these spices dropped during the late colonial period, the Dutch concentrated more on the sugar plantations of Java and 
Sumatra. As such, under Sukarno and Suharto, Ternate was part of Maluku Province (with its capital in Ambon). ${ }^{2}$ In 1999, this province was split into Maluku and North Maluku provinces-the first administrative split in post-authoritarian Indonesia.

During Indonesia's struggle for independence in the 1940s, Jabir Syah-the $47^{\text {th }}$ Sultan of Ternate-refused Sukarno's offer to integrate the Sultanate into the nascent Indonesian republic; this resulted in a soft exile, which lasted until Jabir Syah's death in 1974. At the same time, newly established Indonesian government tried to eliminate the aristocracy. Using a series of land regulations, it prohibited aristocracies from owning land and established ownership ceilings; this allowed the government to claim their material resources. ${ }^{3}$ Nonetheless, the Moluccan people's strong sentiments regarding the aristocracy have never abated. According to one local sociologist, this is because the Sultanate offered the people of Ternate a means of connecting the people of Ternate with their past and incorporating it into their identity. ${ }^{4}$

After the death of Jabir Syah, the Sultanate remained inactive until his son Mudaffar Syah was coronated as the $48^{\text {th }}$ Sultan of Ternate in 1986. Benefitting from his status as a member of the People Representative's Assembly (Majelis Permusyaawaratan Rakyat; MPR), representing Maluku, the new sultan

\footnotetext{
${ }^{2}$ See Law No. 20 of 1958.

${ }^{3}$ See Law No. 5 of 1960 and Law 56/Prp/1960.

${ }^{4}$ Interview with Syafruddin Amin, 25

September 2014, Ternate.

5 Jailolo was formed out of the Ternate Sultanate's area. It consists of approximately
}

maintained strong relationships with adat (indigenous) communities in Ternate as well as western and northern parts of Halmahera Island. When Sultan Mudaffar of Ternate died in Jakarta in February 2015, thousands of people gathered in the street, escorting the palanquin carrying his body in a two-hour procession from the airport to the palace (Kadato). Strong sentiments are similarly held for the Sultanate of Tidore, which historically encompassed the southern part of Halmahera Island and extended eastwards towards Papua (Andaya, 1993), as well as the sultanates of Bacan and Jailolo. $^{5}$ This has had consequences for gubernatorial contestations in North Maluku, as discussed by Wilson (2008).

\section{Land, Political Economy, and Elite Formation}

The literature on land and politics in Indonesia is dominated by four themes: land reform and peasants, land law, forestry and environmental management, and land disputes. In the first, writers concentrate on the implications of land reform for economic distributionespecially as related to landless farmers. Most writers (i.e. Sajogyo, 1970; Selosoemardjan, 1962; Utrecht, 1969, 1973) argue that land reform had enhanced the livelihoods of the Indonesian people until it was stopped by President Suharto in the 1970s. In the second, writers focus on Indonesia's legal framework for land

25 villages along the western coast of Halmahera Island. According to Bubandt (2014, p. 126), the name 'Gilolo' (found in Dutch and Portuguese records) was derived from Jailolo and used to refer to the entire island of Halmahera. 
issues. Most deal with the Basic Agrarian Law (Undang-Undang Pokok Agraria, BAL), which they see as generally having been reduced by actors (thereby limiting its potential operationalisation). Others have emphasised the Forestry Law, introduced by Suharto in 1967, which covers almost $70 \%$ of Indonesia's total area. In the third, scholars have concentrated on forestry and environmental management. Particular focus has been given to the situation since decentralisation began in 2001. Although this resulted in authority over forestry management being delegated to local authorities, it has also created tension between local and national governments. One of the most striking has been a bylaw issued by the Wonosobo Regency Government, which unilaterally stipulated that forest areas previously managed by state enterprises would to be 'communally managed by the people' (Thorburn, 2004). In the last, writers have examined how the overlapping land laws in Indonesia have created conflict in many areas in Indonesia. Land management regulations and policies are unclear, and thus state/corporate actors have often come into conflict with local people/adat communities. The literature on land politics in Indonesia has thus recognised state actors, enterprises, peasants and adat communities, but have not properly considered land as a significant aspect of the political economy in post-authoritarian Indonesia.

Analysis of Indonesia's elite formation has largely ignored the importance of the political economy of land since the late 1960s, when the Suharto government reduced mass politics to a minimum level and focused primarily on ethnicity, bureaucracy, and military matters. A classic work of Crouch (1979), for instance, argues that New Order elites came from military, technocratic, and bureaucratic backgrounds. Moreover, 'the elite of the New Order was dominated by officers and the Western-Educated technocrats who helped them formulate economic policy'. Gregory (1976) similarly found that New Order-era elites came primarily from three institutions (the military, political parties, and technocracy) and were shaped primarily by four aspects: education, social status, religious background, and ethnic origin. She noted, for example, an underrepresentation of non-Javanese in elite formations. Emmerson (1976) defines Indonesian elites as 'members of the higher central bureaucracy and the national legislature.' In his research, he found that elite culture is an interplay between ethnicity and religion, as well as institutional and organisational background. In post-Suharto Indonesia, Shiraishi (2003) writes that the 'majority of local parliamentarians have a background in New-Order era political parties and youth and mass organization.' Therefore, there is a continuation of New Order elites.

To some extent, this current study might expand on previous studies by Savirani (2004) and Hadiz (2010). Using the cases of North Sumatra, East Java, and Yogyakarta, Hadiz explores the political basis of elite dominance in the context of the localisation of power. He argues that 'successful local elites in Indonesia tend to be those who already have access to substantial material resources as well as some degree of control over instrument of political intimidation.' Local elites use material resources for money politics, as well as for corruption activities. This paper is novel, however, in that it contributes to the literature on land and political economy by showing the importance of land control in the political survival of the Sultanate of Ternate. 


\section{Ethnicity, Conflict, and Political Contestation in North Maluku}

Initially, northern Maluku was divided between two regencies, which resembled the islands' traditional aristocracies: the Sultanate of Ternate and the Sultanate of Tidore. North Maluku Regency, with its capital in Ternate, covered an area traditionally controlled by the Sultanate of Ternate; Central Halmahera Regency, with its capital in Soa Sio, covered an area traditionally belonging to the Sultanate of Tidore. On 20 March 1999, Ternate City was incorporated in preparation for the creation of North Maluku Province; by law, a minimum of three regencies/cities was required for a new province to be created (Firman, 2013; Fitrani, Hofman, \& Kaiser, 2005). Four years later, North Maluku Regency was divided into four regencies: West Halmahera, South Halmahera, North Halmahera, and Sula Islands. Central Halmahera, meanwhile, was divided into Tidore City Islands Regency (with its capital in Soa Sio); the capital of Central Halmahera thus moved to Weda. Therefore, the formation of North Maluku Province was an extension of the traditional power of the Sultanate of Ternate, whose traditional territory covers eight of the ten newly established regencies/municipalities in the province.

The formation of North Maluku Province resulted in power struggles, especially in the matter of appointing its first governor. One political party, Golkar, dominated the parliaments of both North Maluku (then still a regency) and Central

\footnotetext{
${ }^{6}$ Ethnicity is identified based on male bloodline. For instance, individuals who trace their heritage to Makian Island will continue to be identified as Makians, even after living in
}

Halmahera after winning the 1999 elections. Sultan Mudaffar, who chaired Golkar's North Maluku branch, was the region's main political actor. He soon became seen as the most likely candidate, as he wielded power in both a traditional institution (the Sultanate of Ternate) and a modern political institution (Golkar). However, according to Wilson (2008, p. 47), three other prominent politicians were also pursuing the governorship: Bahar Andili, the Regent of Central Halmahera; Syamsir Andili (Bahar's younger brother), the Mayor of Ternate City; and Thaib Armaiyn, a longserving bureaucrat. Of these four candidates, only Sultan Mudaffar was of Ternate heritage ${ }^{6}$ the latter three are ethnic Makians, coming from a minority group that had dominated North Maluku's bureaucracy and parliament. Ultimately, as argued by Wilson (2008), Sultan Mudaffar's failure to manage ethnic sentiments and horizontal conflicts resulted in him losing the struggle for governorship.

At the time, North Maluku was engulfed by a bloody conflict, one that began as a land dispute but developed into an ethnic and religious conflict. The Sultanate of Ternate was at the centre of the conflict. In 1975, the North Maluku Regency government-citing the danger of regular volcanic activity-had begun relocating the Makians (most of whom were Muslim) from Makian Island to northern Halmahera, the traditional home of the Kao ethnic group (most of whom were Christian) (Burnet, 2011; Duncan, 2014; Wilson, 2008). After decades of tension, stemming from the Kaos' political and economic marginalisation at the hands

Ternate for generations, if there is no intermarriage with ethnic Ternates. 
of the Makian, open conflict was ignited when the Habibie government issued Government Regulation No. 42 of 1999. This regulation, which created Makian Malifut District in North Halmahera Regency, was seen as violating the Kaos' traditional rights, officially marginalising them in their own lands and acknowledging Malifut as belonging to the Makians. Although most Kaos agreed with the creation of a new district, they opposed the use of the word 'Makian' to describe their land. Nevertheless, their protests failed to influence the Makian-dominated North Halmahera parliament. In August 1999, the first incident broke, when two Kao villages were attacked by Makians. Two months later, Kaos-both Muslim and Christiandestroyed Makian villages in Malifut and expelled all Makians from Kao land, thereby indefinitely ending the discourse regarding the formation of Makian Malifut District. Makians tried to elicit the sympathy of their fellow Muslims, both the ethnic Ternates and Tidores, by describing the conflict in Malifut as a religious one-even though no mosques had been destroyed (Wilson, 2008).

Sultan Mudaffar saw this as an opportunity to increase his political profile, especially in his stronghold of Dufa Dufa, in the lead-up to the gubernatorial selection process. To prevent further conflict in Ternate, Sultan Mudaffar mobilised his traditional guard (pasukan Baru Baru, commonly known as the Pasukan Kuning ['Yellow Squad'] for the colour of their uniforms) to patrol the city and prevent Muslim Makians from retaliating against Ternate's Christians. In this, the Sultan

7 The title Sultan replaced the traditional title following the spread of Islam. Today, these titles are used for different purposes. Kolano is used to represent both the physical and spiritual positioned himself as Kolano, ${ }^{7}$ the protector of all and the bridge between this world and the hereafter. Owing to the minimal presence of military and police personnel in central and northern Ternate, Makians politicians and bureaucrats throughout North Maluku saw Sultan Mudaffar and his Pasukan Kuning as a threat and feared that his governorship would end Makians' domination of local politics. The Sultan's political opponents thus created pan-Muslim solidarity, especially amongst the ethnic Tidores who dominated the southern part of Ternate Island. These opponents created what became known as the Pasukan Putih ('White Squad').

As an extension of the political struggles between Bahar Andili and Sultan Mudaffar, two sultanates were resurrected: the Sultanate of Tidore by Andili and the Sultanate of Jailolo by Mudaffar Syah. The Sultanate of Tidore, which had existed in a vacuum since the 1960 s, was reactivated to challenge Sultan Mudaffar's traditional dominance among the ethnic Ternates, Makians, and other ethnic groups in Ternate, Tidore, and Halmahera. It is thus no surprise that, soon after the coronation, Sultan Djafar Syah of Tidore allied himself with Bahar Andili. In response to Andili's resurrection of the Sultanate of Tidore, Mudaffar Syah recreated the Sultanate of Jailolo in Halmahera, a puppet sultanate that had been destroyed by Ternate in the $17^{\text {th }}$ century (Bubandt, 2014; Leirissa, 1996).

The defeat of Sultan Mudaffar in the conflict between Pasukan Kuning and

worlds, the leader of all human beings and living creatures; it is not restricted to Muslims. The Kolano is seen as the bridge between worlds. 
Pasukan Putih thus mirrored his stance in governorship and continued centuries of rivalry. In his quest for governorship, Andili had successfully reduced Sultan Mudaffar's traditional support by exploiting religious sentiments. Afterwards, Sultan Djafar Syah of Tidore received significant support, which enabled him to successfully contest the 2004 election for the Regional Representative Council (Dewan Perwakilan Daerah, DPD).

Since then, the governorship of North Maluku has continued to be strongly contested. The first Governor of North Maluku, Thaib Armaiyn, came to power in 2002 with the support of the Indonesian Demokratic Party of Struggle (Partai Demokrasi Indonesia Perjuangan, PDIP), the ruling party of the time. Abdul Gafur, a Golkar politician who had also sought the governorship, had received the support of the North Maluku Parliament, but the Central Government had blocked his governorship after Gafur was investigated for alleged bribery. Sultan Mudaffar had been Abdul Gafur's running mate; as such, his aspirations were blocked after the intervention of the Ministry of Internal Affairs (The Jakarta Post, 2002). Ultimately, in North Maluku parliament, Thaib Armaiyn was chosen over Bahar Andili.

In 2007, the North Maluku elections commission (Komisi Pemilihan Umum Daerah Maluku Utara, KPUD Malut) denied Sultan Mudaffar's candidacy after he failed to receive the support of parties representing $15 \%$ of parliamentary seats (based on the 2004 elections); shortly before the deadline, one party-with less than $1 \%$ of votes-had withdrawn its support for Mudaffar. Several days of rioting, involving the Sultan's loyalists and centred on the Baabullah Airport, followed.
Even though Sultan Mudaffar won his challenge in the Constitutional Court, he could not participate in the election, leaving incumbent Thaib Armaiyn and Abdul Gafur to continue their rivalry (Bubandt, 2014).

Ultimately, KPUD Malut declared that Thaib Armaiyn-backed by President Susilo Bambang Yudhoyono's Democrat Party (Partai Demokrat, PD)-had won over Abdul Gafur-supported by Vice President Jusuf Kalla's Golkar Party-the winner by a margin of 900 votes. This decision, however, was annulled by the Indonesian Elections Commission (Komisi Pemilihan Umum, KPU), citing concerns of vote rigging-including two members of KPUD Malut. After KPU conducted a recount, it declared Abdul Gafur the winner. This case, however, was far from over: the Constitutional Court ordered a recount in three regencies. After fifteen months of 'double governorship', the central government intervened for a second time, installing Thaib Armaiyn as governor through Presidential Decree No. 85 /P 2008 (Nurhayati, 2008). KPUD Malut's appeal was denied by the Constitutional Court (Christanto, 2009).

Vote rigging continued in the 2013 governor election. As a result, the Constitutional Court blocked the winner of the second round, Ahmad Hidayat Mus (Regent of Sula Islands Regency), and mandated new elections in seven districts in Sula Islands. Abdul Ghani Kasuba, the incumbent deputy governor, was thus appointed Governor of North Maluku for the 2013-2018 term.

The political history of North Maluku since its creation in 1999 shows that ethnicity has been an integral part of local politics. The people of Ternate lost a series of political contests against candidates from other ethnic backgrounds. Also 
influencing this loss was fragmentation within the sultan's family, as will be discussed in the following section.

\section{Political Fragmentation in the Sultan's Family}

Even though Sultan Mudaffar failed to gain executive office, he readily received support in national legislative elections, representing North Maluku. The Sultan's legislative performance since 1998 was been a continuation of his performance during the Suharto's New Order. Sultan Mudaffar began his political career as a member of Parliament of Maluku in Ambon (serving from 1971 to 1977). After this term's conclusion, he was chosen as heir apparent (Sultan Muda) of the Sultanate of Ternate, but the members of the royal family I interviewed said that he rejected the position and chose to work for various private companies in Jakarta. In 1986, he was inaugurated as the $48^{\text {th }}$ Sultan of Ternate, a position that lacked any significant influence after decades of inactivity. His profile increased as he reactivated the adat communities under his domain, and again when he represented North Maluku in the MPR from 1998 to 2002, during the North Maluku conflict (Anggoro \& Nara, 2010).

In 2004, Sultan Mudaffar won a seat in the National Parliament (Dewan Perwakilan Rakyat, DPR) with the shortlived United Democratic Struggle Party (Partai Persatuan Demokrasi Kebangsaan, PPDK; 2002-2009). He was one of the party's four DPR members, which only

${ }^{8}$ Interview with Ridwan Tjan, 11 November 2014, Ternate.

${ }^{9}$ Ofa is derived from Jong Ofa, an aristocratic title for the sons of the Sultan of Ternate. The received $1.16 \%$ of votes in the 2004 election. He received 24,692 votes, a higher number than the other two members of parliament representing North Maluku. Initially, the Sultan had turned to PPDK because Golkar had not nominated him for deputy governorship (Aryanto, 2002). However, seeing no prospects in PPDK, Sultan Mudaffar left the party and pursued DPD membership in 2009 and 2014. He ultimately passed away in January 2015 , at the age of 79 (Indonesian Elections Commission, 2014).

During Sultan Mudaffar's first term in DPD (2009-2014), several political parties tried to get close to him, not only to receive his support but also to reduce the influence of his fourth wife, Boki Nita Budhi Susanti, who had taken the Sultan's place in DPR. Initially, politicians had hoped that Sultan Mudaffar would give equal support to all parties and placed him above party politics, being the protector of all (as represented by his title Kolano). After Boki Nita, who was allied with the Democrat Party, received significant support in DPD (2004-2009) and DPR (2009-2014), local politicians had no choice other than asking the Sultan to join or become affiliated with their party. According to Ridwan Tjan, the head of the United Development Party (Partai Persatuan Pembangunan, PPP), North Maluku Branch, ${ }^{8}$ Sultan Mudaffar had become an advisor to the North Maluku PPP soon after he secured his seat in DPD in 2009. PPP, meanwhile, supported Sultan Mudaffar's son Ofa Hidayat Syah ${ }^{9}$ in Ternate's 2010 mayoral election and backed his national parliamentary

Sultanate follows a male hereditary line, and all sultans add the title Syah to their name. 
campaign in 2014. In 2014, it was expected that both Sultan Mudaffar and Ofa Hidayat would be PPP candidates, and if the Sultan were elected, he would resign after brief period and give his seat to Hidayat (thereby symbolically showing the smooth political transition in the Sultanate). However, the reality of the matter was different; Sultan Mudaffar refused the agenda for many reasons, and the electoral system changed from a closed list system to an open list system. Furthermore, interviews with local historian Herry Nahrawi and Golkar politicians Asgar Saleh and Syamsir Andili $^{10}$ indicate that the Sultan had 'returned' to Golkar as an advisor in 2013, as symbolised during a visit by Golkar Party Chairman Aburizal Bakrie to the Palace of Ternate's Palace. Parties' competing claims of closeness to Sultan Mudaffar further evidences that they sought to position him as the protector of all parties.

Sultan Mudaffar's political performance in the democratic arena cannot be separated from his immediate family's political journey, including their use of Sultan Mudaffar's charisma and Sultanate symbols to gain political support. Therefore, understanding the political participation of the Sultanate of Ternate should include Sultan's wives and children performance. The following section briefly describes members of the family and their political successes and failures since 1998.

The late Sultan Mudaffar had four wives from four different ethnic backgrounds: Manado-Caucasian, Arab, Ambonese, and Javanese. However, only Boki Nita Budhi Susanti-his fourth wifehas made any inroads in politics. Much about her past life and educational background remains a mystery, and this has become a source of internal conflict (Indonesian Elections Commission, 2009; Kompas Research Department, 2010). Sultan Mudaffar wed Boki Nita, who already had three children from a previous marriage, in 2000. Their marriage was unusual, as no celebration was held. ${ }^{11}$

A brief overview of Sultan Mudaffar's family is presented in the table below.

Table 1. The Family of Sultan Mudaffar Syah

\begin{tabular}{llll}
\hline $\begin{array}{c}\text { Elisabeth Manoppo } \\
\text { (Manado- } \\
\text { Caucasian) }\end{array}$ & \multicolumn{1}{c}{$\begin{array}{c}\text { Thalha al-Mahri } \\
\text { (Arab) }\end{array}$} & $\begin{array}{c}\text { Deetje Drevenlya } \\
\text { Amahorseya } \\
\text { (Ambonese) }\end{array}$ & $\begin{array}{c}\text { Boki Nita Budhi } \\
\text { Susanti } \\
\text { (Javanese) }\end{array}$ \\
\hline $\begin{array}{l}\text { Monalisa Mudaffar } \\
\text { Syah (b. 1958) }\end{array}$ & $\begin{array}{l}\text { Nulzuludin Mudaffar } \\
\text { Syah (b. 1969) }\end{array}$ & $\begin{array}{l}\text { Sofia Mudaffar Syah } \\
\text { (b. 1971) }\end{array}$ & $\begin{array}{l}\text { Nesya Fitri } \\
\text { Handayani (b. 1987)* }\end{array}$ \\
$\begin{array}{l}\text { Iskandar Mudaffar } \\
\text { Syah (b. 1959) }\end{array}$ & & $\begin{array}{l}\text { Wiriawati Mudaffar } \\
\text { Syah (b. 1973) }\end{array}$ & $\begin{array}{l}\text { Nadiah Tsabitah } \\
\text { (b. 1989)* }\end{array}$ \\
\hline
\end{tabular}

${ }^{10}$ Interview with Herry Nahwari on 16 November 2014, Asgar Saleh on 30 October 2014, and Syamsir Andili on 3 November 2014 (all in Ternate). The Sultan replaced Syamsir in Golkar after Syamsir contested the North Maluku governorship, disregarding the party's support for Ahmad Hidayat Mus.

11 Wiriawati and Nulzuludin said that they had not been informed about the Sultan's last wedding, as no celebration was held (Assegaf, 2015). 


\begin{tabular}{|c|c|c|}
\hline $\begin{array}{l}\text { Soraya Mudaffar } \\
\text { Syah (b. 1960) }\end{array}$ & $\begin{array}{l}\text { Firman Mudaffar } \\
\text { Syah (b. 1974) }\end{array}$ & $\begin{array}{l}\text { Hafizt Ayyashy } \\
(\text { b. 1991)* }\end{array}$ \\
\hline $\begin{array}{l}\text { Muhammad Gozali } \\
\text { Mudaffar Syah } \\
\text { (b. 1962) }\end{array}$ & $\begin{array}{l}\text { Sahmardan } \\
\text { Mudaffar Syah } \\
\text { (b. 1977) }\end{array}$ & $\begin{array}{l}\text { Nabila Mariam } \\
\text { Mudaffar Syah } \\
\text { (b. 2002) }\end{array}$ \\
\hline $\begin{array}{l}\text { Usman Mudaffar } \\
\text { Syah (1964-2015) }\end{array}$ & & $\begin{array}{l}\text { Azka Nukila } \\
\text { Mudaffar Syah } \\
\text { (b. 2004) }\end{array}$ \\
\hline $\begin{array}{l}\text { Hidayat Mudaffar } \\
\text { Syah (b. 1966) }\end{array}$ & & 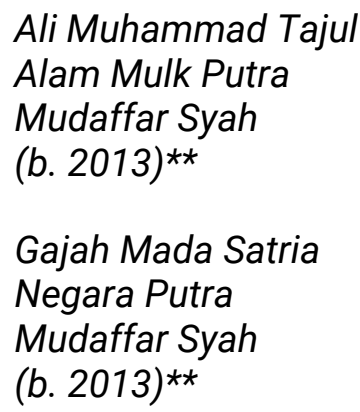 \\
\hline
\end{tabular}

*: Sultan Mudaffar's stepchildren from Boki Nita's previous husband.

**: Contested children due to internal conflict. The court concluded that neither Ali Muhammad and Gajah Mada are Boki Nita's sons.

Although the political performance of the Sultanate of Ternate was largely dominated by Sultan Mudaffar, two other figures within the family have made political achievements. First, the Sultan's fourth wife Boki Nita has been influential in the politics of North Maluku, having served as a member of DPD (2004-2009) and DPR (2009-2014). Her political journey began in 2004 , when she won a whopping $36 \%$ of total DPD votes; the remaining $60 \%$ was divided between four other elected candidates. In 2005, she contested Ternate's mayoral election, losing by a slim margin against incumbent Syamsir Andili. In 2009, she entered DPR with the Democrat Party, 'swapping places' with Sultan Mudaffar, who had been elected to DPD (receiving 57,167 votes, the third most of the province's four representatives). His main support base was in Ternate, where he received 32,569 votes ( $40 \%$ of all DPD votes in the city). However, in 2014, Boki
Nita failed to maintain her seat in DPR. This was largely due to internal tension, as well as her incapacity to receive the support of land-dependent adat communities (as I will discuss later).

Second, since 2004, Sultan Mudaffar's descendants have rarely performed well in elections. Of all of his sons and daughters, only Hidayat Mudaffar Syah has consistently participated in electoral competitions. His career began in 1997, when he was elected the youngest member of the North Maluku local parliament (representing Golkar). In 2004, he ran an unsuccessful parliamentary campaign under the short-lived Pioneer Party (Partai Pelopor, PP). In 2010, he campaigned unsuccessfully for deputy mayor of Ternate; he and his running mate received only $7.8 \%$ of votes, coming in last (Ternate City Elections Commission, 2010). Interestingly, Wahda Z. Imam-his running mate-had been a leader of the Makians 
during the Kuning-Putih conflict of 1999. The union of both Pasukan Kuning and Pasukan Putih leaders, as represented by Hidayat Syah and Wahda Z. Imam, respectively, was part of an electoral strategy to gain the support of both ethnic Ternates and Makians. Finally, in 2014, Hidayat was backed by PPP in an unsuccessful parliamentary campaign, in which he competed against the Democrat Party-backed Boki Nita. In none of these competitions did Hidayat Syah receive significant electoral support.

Thirdly, Sultan Mudaffar's descendants have contested elections with the backing of many different parties, showing that their political careers have been more a matter of luck (benefiting from the Sultan's influence) rather than persistent effort and political calculations. As seen in Table 2 below, Sultan Mudaffar's children have been dispersed amongst many parties. In 2004, Ofa Hidayat and Ofa Gozali contested elections with the backing of parties that differed from those of their father; the former has changed party affiliations several times. In 2014, six of the sultan's children campaigned with six different parties.

Of Sultan Mudaffar's seven descendants (six children and one grandchild) who have contested elections, only his daughter Soraya had made inroads: during the 2004 election in the Sultan's stronghold in West Halmahera, where she benefitted greatly from her father's charisma. Ultimately, she only occupied the seat for six months, not only due to transportation difficulties-it was approximately ninety minutes by speedboat from Dufa-Dufa in Ternate to Jailolo-but also due to her lack of interest

${ }^{12}$ Interview with Soraya Mudaffar Syah, 12 November 2014, Ternate. in politics. Sultan Mudaffar had asked her to become involved. In an interview regarding her involvement in the 2004 election, Soraya explained: ${ }^{12}$

At the time, my father was more powerful than his sons or daughters. The party was not as popular as my father. I never campaigned (for myself) and I never (volunteered) to join that party. My father asked me to join (the election); just like that. (You) must win. That's all right. I did nothing. My father asked me (to compete).

Two or three years ago, he told me as I am not a highly educated woman, just a Grade 12 graduate, (I did not continue my studies) because of economic factors. At the time, my father did not have enough money to send us to university. Only Hidayat went to university, in Bandung. He said: 'You don't need a high level of education. You'll be too busy (doing assignments). Later I will make you the deputy mayor of Ternate.'

Interestingly, despite limited previous electoral success, many still campaigned in 2014 election. Ultimately, seven members of the family participated in legislative elections at the national, provincial, and local levels. None but Sultan Mudaffar succeeded. In addition, the 2014 election was also marked by the participation of Sultan Mudaffar's granddaughter, Achita Nurain Zulkarnain (daughter of Soraya Mudaffar Syah), who was backed by the Golkar Party in the Ternate municipal election; in this, she challenged her uncle Firman Mudaffar Syah (backed by the National Mandate Party, [Partai Amanat Nasional, PAN]) and her aunt Wiriawati Mudaffar Syah (backed by the Crescent Moon Party [Partai Bulan Bintang, PBB]). 
respectively. None received the 500-1500 votes needed to be elected.

Wiriawati received 367 votes and 29 votes,

Table 2. Political Participation of Sultanate of Ternate Family Members, 2004-2014

\begin{tabular}{|c|c|c|c|c|c|}
\hline & 2004 & 2005 & 2009 & 2010 & 2014 \\
\hline Sultan Mudaffar & $\begin{array}{l}\text { DPR RI } \\
\text { (PPDK) - } \\
\text { Won }\end{array}$ & - & $\begin{array}{l}\text { DPD RI - } \\
\text { Won }\end{array}$ & - & $\begin{array}{l}\text { DPD RI - } \\
\text { Won } \\
\text { (73,815 } \\
\text { votes) }\end{array}$ \\
\hline $\begin{array}{l}\text { Boki Ratu Boki } \\
\text { Nita Budhi } \\
\text { Susanti (fourth } \\
\text { wife) }\end{array}$ & $\begin{array}{l}\text { DPD RI - } \\
\text { Won }\end{array}$ & $\begin{array}{l}\text { Mayor of } \\
\text { Ternate } \\
\text { Lost (came } \\
\text { in second) }\end{array}$ & $\begin{array}{l}\text { DPR RI (PD) } \\
- \text { Won }\end{array}$ & - & $\begin{array}{l}\text { DPR RI (PD) } \\
- \text { Lost } \\
(25,685 \\
\text { votes) }\end{array}$ \\
\hline $\begin{array}{l}\text { Hidayat Mudaffar } \\
\text { Syah (son, from } \\
\text { first wife) }\end{array}$ & $\begin{array}{l}\text { DPR RI (PP) } \\
\text { - Lost }\end{array}$ & - & - & $\begin{array}{l}\text { Deputy } \\
\text { Mayor of } \\
\text { Ternate- } \\
\text { Lost (came } \\
\text { last) }\end{array}$ & $\begin{array}{l}\text { DPR RI } \\
\text { (PPP) - } \\
\text { Lost (5,108 } \\
\text { votes) }\end{array}$ \\
\hline $\begin{array}{l}\text { Monalisa } \\
\text { Mudaffar Syah } \\
\text { (daughter, from } \\
\text { first wife) }\end{array}$ & $\begin{array}{l}\text { DPRD } \\
\text { Ternate } \\
\text { (PPDK) - } \\
\text { Lost }\end{array}$ & - & - & - & - \\
\hline $\begin{array}{l}\text { Soraya Mudaffar } \\
\text { Syah (daughter, } \\
\text { from first wife) }\end{array}$ & $\begin{array}{l}\text { DPRD West } \\
\text { Halmahera } \\
\text { (PPDK) - } \\
\text { Won }\end{array}$ & - & - & - & - \\
\hline $\begin{array}{l}\text { Muh. Gozali } \\
\text { Mudaffar Syah } \\
\text { (son, from first } \\
\text { wife) }\end{array}$ & $\begin{array}{l}\text { DPRD } \\
\text { Ternate } \\
\text { (PDIP) - } \\
\text { Lost }\end{array}$ & - & - & - & - \\
\hline $\begin{array}{l}\text { Iskandar } \\
\text { Mudaffar Syah } \\
\text { (son, from first } \\
\text { wife) }\end{array}$ & & & $\begin{array}{l}\text { DPR RI } \\
\text { (PKP) - } \\
\text { Lost }\end{array}$ & - & $\begin{array}{l}\text { DPRD North } \\
\text { Maluku } \\
\text { (Golkar) - } \\
\text { Lost }\end{array}$ \\
\hline $\begin{array}{l}\text { Firman Mudaffar } \\
\text { Syah (son, from } \\
\text { third wife) }\end{array}$ & - & & - & - & $\begin{array}{l}\text { DPRD } \\
\text { Ternate } \\
\text { (PAN) - } \\
\text { Lost (367 } \\
\text { votes) }\end{array}$ \\
\hline $\begin{array}{l}\text { Wiriawati } \\
\text { Mudaffar Syah }\end{array}$ & & & - & - & $\begin{array}{l}\text { DPRD } \\
\text { Ternate }\end{array}$ \\
\hline
\end{tabular}




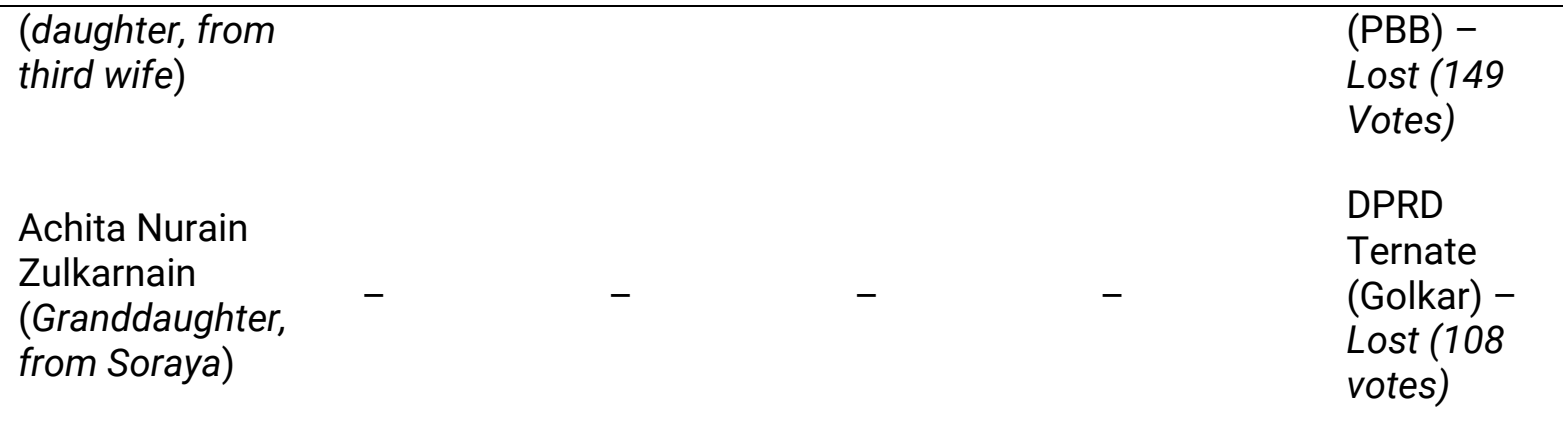

Source: Official election results, 2004-2014.

The participation of the Sultanate's family members in the 2014's election, in which only Sultan Mudaffar was successful, was a clear example of internal fragmentation within the family. Rather than choose a prominent political party as their vehicle, members of the aristocracy were targeted by small and short-lived political parties that required the support of traditional leaders to increase their popularity. Neither PPDK and PP, which were used in 2004, passed the parliamentary threshold for the 2009 election; both dissolved shortly after the election. Boki Nita had successfully represented the party of then-president Susilo Bambang Yudhoyono in 2009, but suffered from the massive loss of support for the party after massive corruption was reported.

Boki Nita's selection of different political parties represents internal conflict, both between Boki Nita and Sultan Mudaffar's other wives and children and between Boki Nita and the adat community. This conflict peaked when, two years before the Sultan's death, she made a claim regarding a 'twin sultan' that challenged the most important aspects of Ternate's maledominated Islamic society. As a result, both

\footnotetext{
${ }^{13}$ Islam has had significant influence on the history and politico-social structure of the
}

adat communities and the Sultan's children banded together to oppose Boki Nita. ${ }^{13}$

Several other incidents have been detrimental to Boki Nita's relationship with adat communities. First, she built a 'women's mosque' next to Grand Mosque (Sigi lamo), the Sultanate's second-most important site after the palace. Second, she has positioned herself as equal to the Sultan, extending the palanquin tradition to include not only carrying the Sultan to Sigi Lamo but also to carry herself to the 'women's mosque'; in this, the Sultan's palanquin is used. The third source of conflict has been her reshaping of the Sultanate's structure, which is seen as going against centuries of tradition. This has resulted, for instance, in the displacement of the Sultan's brother, Kapita Lao Effendi Syah.

The most significant internal conflict, which has deeply influenced the political performance of her children with the Sultan, was the nomination of two boys (claimed to be Boki Nita's sons) as 'twin sultans' (Kolano Maduro). In 2013, Boki Nita-then 41 years old-claimed to have delivered twin boys fathered by 77-year-old Sultan Mudaffar. On September 11, 2013, when the senior twin Ali Muhammad and junior twin Gajah Mada were three months old,

Ternate Sultanate. See, for instance, Andaya (1993), Lay (2001), Putuhena (1980). 
the boys were declared were declared the 'twin young sultans' (Kolano Maduro) by decree of the Sultan (Jaib Kolano). Until the boys reached the age of majority, Boki Nita would act as regent. Through this decree, the succession processes in the Sultanate of Ternate were transformed by introducing the Javanese concept of crown prince (Sidik, 2013; Usman, Husain, \& Saraha, 2014). It eliminated the role of the Bobato 18 , concentrating political and economic power in the hand of the Sultan and forcing an inland aristocratic structure on Ternate. This internal conflict significantly affected the political performance of the Sultan's family in the 2014 election.

Boki Nita's influence ended when the Sultan died in February 2015; the people of North Maluku were loyal only to Sultan Mudaffar. In January 2015, when the Sultan was spending his last days unconscious in his deathbed, a new Kapita Lao-the son of previous Kapita Lao, Effendy Jabir Syahwas inaugurated. Boki Nita was refused access to the Sultan when he was being treated at Pondok Indah Hospital in Jakarta; she was likewise prevented from joining her husband's funeral in Ternate (Malut Post, 2015). Two weeks later, her queen title (boki) was rescinded (Marwoto, 2015); her supporters in the Sultanate's structure were removed; and a new Bobato 18 , traditionally responsible for choosing the next sultan, was established (Kasman, 2015). In August 2015, Boki Nita was investigated for suspected identity fraud regarding her twin sons; ultimately, she was sentenced to 18 months imprisonment. Her political career thus ended with the death of her political patron.

Boki Nita's attempted abolishment of the Bobato 18 was a perfect example of her incapacity to understand the politicoeconomic relations within the Sultanate.
The eighteen delegates represented by Bobato 18 were the leaders of the adat communities integrated into the Sultanate of Ternate. Unlike the centralised political system in Java, the Sultanate of Ternate was a federalist sultanate that depended heavily on the adat communities spread around Ternate and the surrounding islands. This will be explored below.

\section{From coastal to land-based aristocracy}

The sultanates and kingdoms of Southeast Asia have been variously identified as coastal and land-based (Bastin \& Benda, 1968; Wolters, 1970). The coastal aristocracies of Indonesia are characterised by the 'absence of land property'; they rely on trade and fishery products, orient their palaces toward the sea, are ethnically heterogenic, and utilise a decentralised power structure. As such aristocracies rely on their control of harbours, their facilities, and the flow of goods, land property is not an important element of their economic and political power (Siddique, 1977). Coastal aristocracies tend to build up their navies to protect their interests. Naval chiefs are very important in their aristocratic structure, and most are either members of the inner family or the aristocracy.

On the contrary, inland aristocracies strongly emphasise agriculture, and water farming is an important political and economic element. Siddique (1977) characterises the agrarian proto-state as being characterised by social division (court and peasantry), court control over the agrarian economy, the absence of a substantial land-owning class, and administrative power being channelled through an appointive quasi-bureaucratic nobility. Wittfogel (1967), in his classic 
work, notes that the largest aristocracies are hydraulic societies and civilisations that depend on water systems for rice field irrigation. The Unlike agrarian societies, which develop small-scale irrigation systems, hydraulic societies exert significant control over water-up to and including creating flood control systems.

The political structure of Ternate Sultanate was never designed as a landbased aristocracy; it was intended for a commercial aristocracy, one that strongly emphasised naval power and benefited greatly from the geographical conditions of Ternate. Geographically, the palace faces the sea and has its own port; together with its surroundings, known as Dodoku Ali, have been the sultanate's most important infrastructures for centuries. Second, Ternate's military forces (now the palace guard) are under the command of the Kapita Lao (the captain of the sea), a position traditionally held by the Sultan's brother. This Kapita Lao was traditionally responsible for both maritime trade and security, and thus the position was one of the most important in the sultanate. Third, institutionally, the Sultanate of Ternate has no special section for recording and managing land issues. Such issues are handled by the General Secretary of the Sultanate (Tuli Lamo), which is also responsible for many other affairs. The Tuli Lamo is required to possess a mastery of both Arabic and the Ternate language, further emphasising the importance of trade. Fourth, Ternate has no rivers and only limited fertile land on the slopes of Mount Gamalama. As such, it could not possibly create the hydraulic society

${ }^{14}$ Sultan Jabir Syah's position in the Ministry of the Interior Minister was unclear. He had no staff and no definite tasks. described by Wittfogel (1967); indeed, before rice was imported, sago was the staple foodstuff in Ternate. Finally, traditional activities and rituals have emphasised the sea. This includes Kololi $\mathrm{Kie}$, a ritual that involves circling the island by sea.

In the 1950s, during the reign of Sultan Jabir Syah, the Indonesian government replaced Ternate as the ruling sea trade authority. During this period, Ternate's sultanate was dismantled and inactive. Sultan Jabir Syah had been close to the Allies during the Indonesian National Revolution (1945-1949), and was the only Sultan who was 'saved' by the Dutch when the Japanese invaded in 1943. After his return to Ternate in 1945, Sultan Jabir Syah served as commanding officer of Netherland Indies Civil Administration (CONICA), leading a regional detachment of the Dutch-run semi-military organisation. During the United States of Indonesia era, when Maluku was part of the State of East Indonesia, Sultan Jabir Syah not only refused to become part of the Unitary Republic of Indonesia but also sought to buttress his position by creating a coalition between the sultanates of eastern Indonesia (Amal, 2010). After independence, President Sukarno exiled the Sultan to Jakarta, where he held an idle position (Pejabat Tinggi Diperbantukan) ${ }^{14}$ under the Minister of the Interior. He visited Ternate only a few times before his death (Djaafar, 2005). When his son, Sultan Mudaffar, reactivated the Sultanate in 1986, it had already lost access to the economic revenue produced through trade. 
Land, therefore, was its only available means of controlling its adat subjects.

The Sultanate of Ternate has traditionally enjoyed a political basis at the village and district level, wherein adat communities pledge their loyalty to the Sultanate while simultaneously positioning themselves as his subjects. The Sultan chooses their leaders to serve as his vassals, but at the same time grants them rights in the succession process. Traditionally, the Sultan is chosen by an eighteen-member council known as Bobato 18 (Bobato Nyagimoi se Tufkane). Members consist of adat communities, and collectively represent the 41 clans (soa) of Ternate $^{15}$ (Leirissa, 1996; Soelarto, 1976). During succession, it is the highest institution in the Sultanate of Ternate, and responsible for choosing the next sultan (Syah, 2009, pp. 6-7). It may choose the next Sultan from any of the late Sultan's sons and grandson, following the male hereditary line. Its decision is only deemed valid if its meetings are attended by the Kapita Lao, even though he has no voice. There is thus a mutually reciprocal relationship between adat communities and the Sultan: the Bobato 18 chooses the new sultan from among the late Sultan's sons and grandsons, then become the subjects of this new sultan.

\footnotetext{
15 The Bobato 18 council consists of eighteen adat communities, which are identified with different names based on their territorial area: five kimalaha (Marsaoli, Tomaito, Tomagola, Tamadi, and Payahe), four fanyira (Jiko, Jawa, Tolangara, and Tabala) and nine sangaji (Tamajiko, Malayu, Limatahu, Kulaba, Malaicim, Tobolen, Tafmutu, Tafaga, and Takafi).

${ }^{16}$ See the Basic Agrarian Law (BAL), Law No. 5 of 1960.
}

The unity between the Sultan and adat communities is evident in many ways. The Sultanate's emblem, the Limau Gapi (a two-headed eagle with a single heart), symbolises two leaders (i.e., the Sultan and the adat communities) with a common interest. Similarly, the people of Ternate often make cones of 'yellow rice' topped by an egg. The rice symbolises the people (bala), while the egg symbolises the Sultan (kolano); it thus indicates that the Sultan can only stand with the support of the people. Unity is further underscored by the colour of the dish: inside the white egg is yellow yolk, and inside the yellow rice is white rice (Syah, 1998). The unique 'democratic' form of the Sultanate of Ternate is quite unlike that of Indonesia's other sultanates, and has been perceived as the origin of Indonesia's political structure-or, at least, during the New Order era (1968-1998), when the president was chosen by the MPR, just as the Sultan of Ternate is chosen by the Bobato 18 council.

The unique structure of Sultan-adat relations in Ternate have been economically and politically beneficial in post-authoritarian Indonesia. Economically, customary land is not subject to the $1960 \mathrm{BAL},{ }^{16}$ and as such adat communities have maintained access to and control of land. ${ }^{17}$ Moreover, even though the BAL abolished land ownership for current and former sultanates, its

\footnotetext{
17 See Article 3 of Law No. 5 of 1960: "In regard to abovementioned Article 1 and 2, the implementation of ulayat rights and similar rights from indigenous law communities, if they exist, has to be concordance with national and state interests, based on national unity, and not contradict other laws and higher regulations."
} 
framing of customary land was open to exploitation. In the case of Ternate, the sultanate has had the authority to use land through cocatu (royal decrees granting land to farmers while maintaining adat ownership). Many of the adat communities affiliated with the Sultanate are spread throughout the previous North Maluku Regency, but the strongest support has always come from Ternate.

Based on Ternate's customary law, the sultanate's land is the land that is managed and controlled by the Sultan but not owned by him. ${ }^{18}$

Even though the Sultanate of Ternate has historically relied on maritime trade and naval might, it has created rigid regulations related to agrarian issues. First, it distinguishes between coastal/sea management and management. The former is permanent, while the latter may be either temporary or permanent; individuals must exercise several temporary before being granted permission to permanently manage land. In some areas, the sultanate's people still guard the land. Such a practice has been used for centuries.

The Sultanate of Ternate divides maritime affairs into three categories, based on distance from the coast. The first is Ngolo Sahe, covering the coastal areas where people normally swim. Adat communities can harvest oceanic products in this area, including seaweeds, crabs, prawn, fish etc. Secondly, the deeper areas, where people cannot swim and fishermen require nets, is called Ngolo Ngido. Last is the open sea, called Ngolo Lamo. Such management is important in mediating

18 Interview with Gunawan, Tuli Lamo (secretary) of the Ternate Sultanate, 22 October 2014, Ternate. disputes between fishermen, especially as modern equipment has been used. Larger boats are only allowed to operate in Ngolo Lamo, while more traditional fishermen can exploit Ngolo Ngido using simple nets and rods.

Adat communities receive temporary land rights based on the assumption that land was previously a forested area controlled by the Sultanate of Ternate. Temporary land usage rights begin with Tolagumi (cutting the rope), which is related to the traditional belief that designated forests were owned by the spirit world and that special ceremonies were necessary. This process must be approved by the Sultan in his capacity as Kolano, master of the seen and unseen worlds. By making offerings, adat people officially 'cut the rope' between the spirit world and designated forests. Tologami mostly involves communities. The second right is safa right ('cutting and peeling'), which allows the adat community to exploit forests by cutting and peeling the outer parts of trees, or by collecting resin; felling trees is not permitted. In this system, the first person to peel trees is the first to receive temporary rights. Third are Ruba Banga (forest opening) rights, which provide individuals with the right to fell trees and cultivate more economically viable crops (Taib, Soetarto, \& Tonny, 2010).

Permanent land usage is fully under the control of the Sultan, as Kolano, but may be transferred to adat communities. Even though land is under the control of the sultanate, adat rules prohibit the Sultan from owning land individually (Asyhari, 
2008). The Kolano receives two types of rights: Aha Kolano and Raki Kolano. The former is mainly used for food security, while the latter is used for other economic purposes. Only sago palms (metroxylon sagu) may be planted on Aha Kolano land, while other crops may be cultivated on Raki Kolano land. Both can be transferred to individual and adat ownership by decree. Before such a decree may be issued, the adat community or individual must be part of the sultanate's traditional structure and demonstrate their loyalty. The cocatu includes detailed administrative information about the land, including its size $^{19}$ and borders, as well as the name of the sultan and the subject. Signed and administered by the Tuli Lamo, this document has no time limit to its usage rights. Most Aha Kolano and Raki Kolano rights have distributed to adat communities since the $15^{\text {th }}$ century.

The lands distributed to the adat communities may be owned by communities or individuals. Communityowned lands, known as aha soa, are managed by village chiefs, known as fanyira or kiemalaha. However, such rights have yet to be recognised by national law (Asyhari, 2008). The second type of traditional land right, called aha cocatu, confers individual ownership. This ownership is recognised by special decree; previously written in the Malay and Ternate languages (using the Arabic script), since 1960 such decrees have been used by the Ternate Land Office as proof of ownership when issuing private land ownership rights. ${ }^{20}$

19 The Sultanate uses depa for land measurement. It is approximately the hand span of a 1.7-meter-tall adult male. Ten depa is equal to one taran (Asyhari, 2008).
Aside from the non-palace lands discussed above, the Sultanate of Ternate also has control over its palace land. These include the palaces (Kadato [main palace] and Kadato Ici [small palace]), the royal grounds (Ngara Lamo [main grounds] and Ngara Ici [small grounds]), the port (Dodoku Ali), three mosques (Sigi Lamo, Sigi Cim, and Sigi Heku), as well as several retreats and places around Ternate and West Halmahera. However, like other aristocratic artefacts in Indonesia, these lands have been subjected to the $1960 \mathrm{BAL}$ and the national legal certification process.

Politically, both adat communities and the Sultanate are in mutually exclusive relationship. As such, adat communities have always given their votes to the Sultan. On one hand, the Sultan is representative of adat; on the other hand, he requires their support. This mutual relationship has been strengthened by the adat communities' loyalty to the Sultan. Gunawan, the sultanate's general secretary, describes this loyalty as follows:

On one occasion, the minister was scheduled to come to the Kadato (palace) at 1 p.m. At 10 a.m., the Sultan said that he needed no more than 500 people to gather at Kadato at 1 p.m. By 1 p.m., more than 1,000 people had gathered at the Kadato. If, three hours previously, he had asked (for) 1,000 people to come, 1,500 would have come. They all came with adat clothes. They gave up everything they were doing to

${ }^{20}$ Focus Group Discussion with the head of Ternate Land Office and his staff, 18 November 2014, Ternate. 
answer the Sultan's call. This has happened many times. ${ }^{21}$

On some occasions, he used the traditional Gura Gam ceremony wherein adat communities gathered to meet the Sultan to campaign for himself and Boki Nita. He also used the kololi kie tradition to meet with supporters. On all such occasions, adat communities voluntarily gathered and prepared for the Sultan's visit. Such a visit was perceived as an honour.

As a central part of the economic and political structure of the Sultanate of Ternate, any challenge against sultanate's supremacy in adat land would face significant challenges. This can be seen in the case of the Hypermart supermarket, located a few hundred meters from the palace. Hypermart, a subsidiary of the Lippo Group, was built on reclaimed land after signing a contract with the Ternate City Government. It has become an important part of Ternate's economy, as Lippo invested Rp 150 billion (US\$ 15 million) and created 350 jobs. According to Indonesian land law, $^{22}$ ownership of reclaimed land is granted to those who have transported land to the reclamation site (in this case, the Ternate City Government). However, this land is located in the sultanate's traditional domain, part of Ngolo Sahe, the circumlittoral area. ${ }^{23}$

Ultimately, the Lippo group was only willing to deal with the Ternate City Government, and the Ternate City Land Office did not provide a definite solution or official written recommendation (Ternate City Land Office, 2014). Syamsir Andili had

\footnotetext{
${ }^{21}$ Interview with Gunawan, Tuli Lamo (secretary) of the Ternate Sultanate, 22 October 2014, Ternate.

22 See Presidential Decree No. 122 of 2012.
}

begun the reclamation to create open space, and had never intended to construct buildings in the area. Construction had begun under Burhan Abdurahman, a mayor of Tidore heritage. In this, Burhan was supported by the Sultan Mudaffar; his deputy mayor was the sultan's nephew. However, he faced strong protests from other members of the Sultan's family. The Sultanate, in this case represented by Boki Nita, protested that the Ternate Government had not consulted the Sultanate regarding the reclamation and encroached on the Sultanate's asset (Seputar Malut, 2014). Boki Nita threatened to mobilise adat forces (bala kusu sekanokano) to occupy Hypermart (Kabar Timur, 2014). Although this threat was never realised, it was sufficient for Hypermart to sell of its stock at deep discounts and close its store-only months after its grand opening. It re-opened a few days later.

Many of my informants claimed that, at the time, Boki Nita required financial support to finance her 2014 election campaign. She was always the Sultanate's representative in negotiations regarding Hypermart, while the Ternate City Government wanted to directly discuss the matter with Sultan Mudaffar. Ultimately, however, this case did not bolster support for Boki Nita, but was detrimental to her public image among voters in southern and central Ternate (many of whom benefited from Hypermart). The case seems to have stagnated after July 2014, not only because of Boki Nita's disappointing electoral results but also because of the succession scandal. The Hypermart case show how

${ }^{23}$ Traditionally, ownership of land controlled by the Sultanate was granted through Aha Cocatu, while ownership of land controlled by the Dutch colonial regime was granted through eigendom. 
members of the Sultan's family failed to control land access during their political activities, as will be elucidated below.

\section{From Land Control to Ballot Box}

To measure political support in Ternate is to understand the interplay between ethnic and geographical boundaries. During the province's early years, land, ethnicity, religion and communal conflict was used by politicians to improve their political support or to undermine their rivals (Duncan, 2014; Klinken, 2007; Wilson, 2008). In 2014, Ternate City consisted of seven districts, with uneven population distribution. The three largest, South, Central, and North Ternate, represented $87 \%$ of Ternate's total population. Around $34 \%$ of Ternate's population lived in South Ternate; $28 \%$ lived in Central Ternate; and 25\% lived in North Ternate (BPS-Ternate, 2014). North Ternate's population is predominantly of Ternate heritage, while South Ternate has a more heterogeneous population, one that is dominated by the Makayoas (Makian/Kayoa), Tidores, and Javanese. Such segregation was created during the colonial period, when the area south of Fort Orange was under colonial rule, while the Melayu Cim mosque northward was controlled by the Sultanate of Ternate. Central Ternate blended both, with south and north being demarked by Kesatrian Road.

Electoral constituencies in North Maluku Province, both DPR and DPD, have largely been determined by traditional ethnic lines. In the 2014 election, North Maluku Province had three DPR representatives and four DPD representatives. For the North Maluku Parliament, Ternate City and West Halmahera district constituencies have strong relations with the Ternate Sultanate. DPRD Ternate has four constituencies, marked by district boundaries: first, South Ternate and Moti Island; second, Central Ternate District; third, North Ternate; and fourth, Ternate Island, Batang Dua Island and Hiri Island (Ternate City Elections Commission, 2014).

Therefore, it is not surprising that Ternate royal family members have maximised their support in its traditional northern domains. In the 2014 election, Sultan Mudaffar (DPD), Boki Nita (DPR, PD) and Hidayat Mudaffar Syah (DPR, PPP) competed in the North Maluku Province constituency. Iskandar Mudaffar Syah (DPRD Malut, Golkar) competed in Ternate City and West Halmahera Constituency. In the Ternate Parliament, three family members competed, in Central Ternate (Achita-Golkar), North Ternate (Firman Syah, PAN) and Ternate Island, Batang Dua Island, and Hiri Island (Wiriawati, PBB) constituencies, respectively. None competed in the South Ternate and Moti Island constituencies. The figures below show the election result for DPR and DPD of the Ternate Sultanate in the Ternate constituencies from 2004 to 2014; due to administrative divisions in each election, the figures are divided into three tables, representing three consecutive elections. 
Figure 1. Sultan Mudaffar and Boki Nita: Performance in 2004 Election

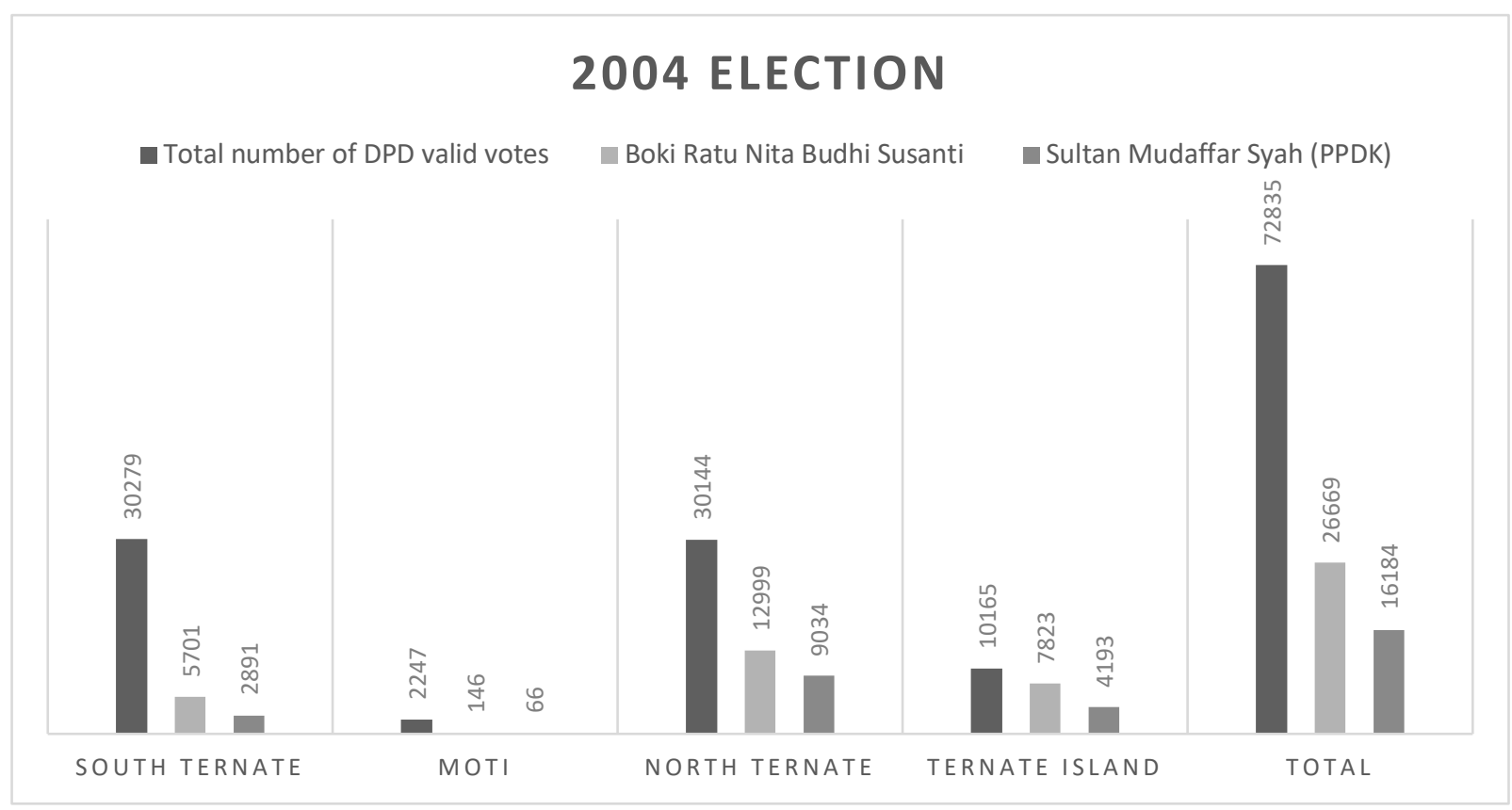

Source: Smith (2009, Annex D)

The above figure shows that, in the 2004 election (with four districts), both Sultan Mudaffar (DPR-PPDK) and Boki Nita (DPD) received relatively similar electoral support from the Sultanate's traditional area in the northern Ternate and Ternate Island Districts. Sultan Mudaffar's campaign in North Maluku was more difficult than Boki Nita's, as he had more political rivals and was running with a relatively unknown party. In North Ternate, Boki Nita received $43 \%$ of valid DPD votes. While data on the total number of DPR votes are not available, it is known that Sultan Mudaffar received 9,034 votes; assuming that the total number of valid votes were not significantly unlike those of 2009 and 2014, Sultan Mudaffar received almost a third of the valid DPR votes. In Ternate Island District, Boki Nita received massive support (76\% of votes), while Sultan Mudaffar received 4,193 votes (almost half of all valid votes). Of the three candidates seeking to represent North Maluku, the Sultan by far received the most votes: a total of 16,184 votes. For comparison, Abdul Gani Kasuba (Partai Keadilan Sejahtera, PKS) received 5,425 votes and Abdul Gafur (Golkar) received 5,670 votes (Smith, 2009). 
Figure 2. Sultan Mudaffar and Boki Nita: Performance in 2009

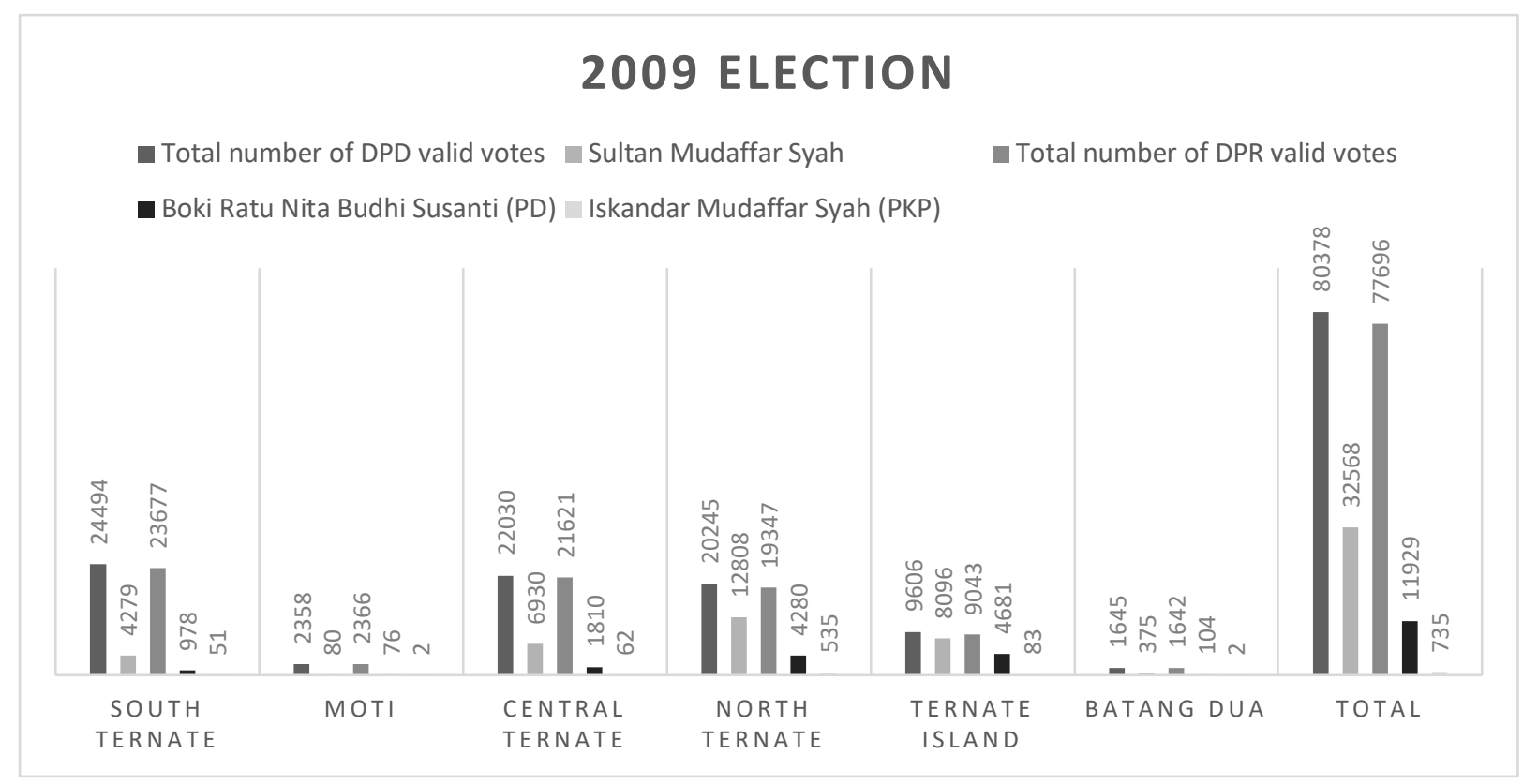

Source: Ternate City Elections Commission 2009

The 2009 election produced similar results, wherein both Sultan Mudaffar (DPD) and Boki Nita (DPR, PD) received support from the Sultanate's traditional area. Central Ternate District had been created out of South Ternate and North Ternate districts, while Batang Dua had been created out of Ternate Island District. Both Sultan Mudaffar and Boki received massive support in North Ternate and
Ternate Island districts, and to some extent in Central Ternate. They had less success in South Ternate and Moti. In North Ternate, Sultan Mudaffar received $63 \%$ of all valid DPD valid votes (competing among 27 DPD candidates), while Boki Nita received $22 \%$ of all valid DPR votes (competing among 81 DPR candidates). These included her son in-law Iskandar Syah, who received only 735 votes. 
Figure 3. Sultan Mudaffar, Boki Nita and Hidayat Syah: Performance in 2014

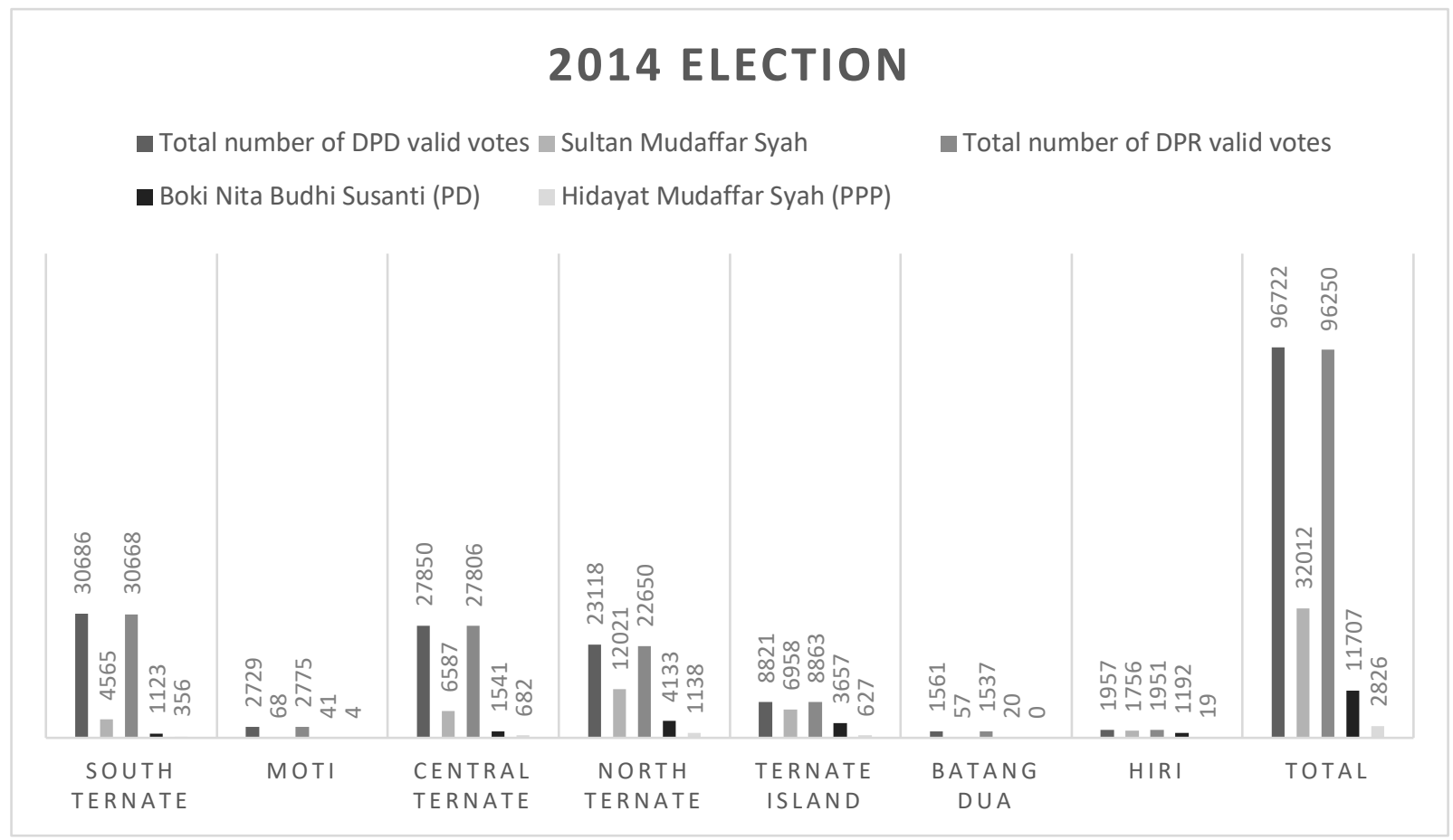

Source: Ternate City Elections Commission, April 2014

A similar trend was identified in the 2014 election, wherein Sultan Mudaffar again received the support of the Sultanate's traditional area; running amongst 32 candidates, he received $30 \%$ of all valid DPD votes in Ternate. In the newly formed Hiri Island District, long home to Sultanate loyalists, Sultan Mudaffar received an enormous $89 \%$ of valid DPD votes, while Boki Nita (running amongst 36 candidates) received $60 \%$ of all valid DPR votes. In North Ternate, Sultan Mudaffar received more than half of all valid votes. In North Maluku constituency, Boki Nita received 25,685 votes and Hidayat received 5,108 votes, but neither received a seat. Boki Nita received 2,500 fewer votes than Mohammad Yamin Tawary, running with the National Mandate Party (Partai Amanat Nasional, PAN).

The above figures show that Sultan Mudaffar's political support came from areas where he controlled traditional land. In order to maintain political support, he used both the material basis of land and traditional practices. In terms of land control, he continued the traditional practice of distinguishing between temporary and permanent rights. Meanwhile, in terms of traditional practices, he used both kololi kie and gura gam to meet with his loyalists. Unlike other politicians, who must finance their visits to communities, adat communities considered Sultan Mudaffar's visits an honour. With the acknowledgement of cocatu as a means of transferring ownership and registering it in the national land system, this material relationship became stronger.

On the contrary, the capacity to turn land into political support was not transferred to Hidayat or Boki Nita. Hidayat did not receive control of land rights, as he is not sultan, while Boki Nita-as shown 
previously in the Hypermart case-has had no capacity to use land issues for her electoral benefit.

\section{Conclusion}

This article discusses one of few surviving aristocracies in Indonesian electoral politics, which exists within a newly formed province where ethnic identities remain strong. It demonstrates how the Sultanate of Ternate has been relatively successful in its political endeavours. Before his death in 2014, Sultan Mudaffar had won every electoral competition he contested since the beginning of political reform. His wife and immediate family, meanwhile, have a mixed record. I argue that Sultan Mudaffar's individual success stemmed from his capacity to transform land control into political support, as shown in the electoral results from areas traditionally under his control. His family failed to achieve a similar level of success, owing both to their inability to control land and internal fragmentation within the family. Rather than establish political coalitions and dominate local politics, family members have used newly formed political parties to gain support amongst the ethnic Ternate.

This paper gives an alternative answer to the King's Dilemma advanced by Huntington (1968), wherein monarchies would lose their influence as a result of modernisation and reform. The case of Ternate shows that, in a multi-ethnic society where the dominant ethnic group is struggling to maintain political supremacy, the Sultanate is seen as the cornerstone of their efforts to defend their ethnic interests. During the formation of the North Maluku Province, the ethnic Ternate had lost political control even though Sultan Mudaffar played a prominent role in the province's creation. Both the Sultan and adat communities benefited; the Sultan received political support by controlling traditional land use, while the Ternate people were able to defend their access to traditional land-an important part of their identity and livelihood.

Moreover, Corbett, Veenendaal, \& Ugyel (2016) argue that personal attachment is key to the survival of small monarchies. I argue that, even though monarchy personalisation is important for accumulating political support and ensuring the survival of the monarchy, it cannot be analysed without considering the politico-economic relationship between leaders and their people. By analysing the political history of Ternate more deeply, this article suggests that material resources are also key to the survival of the aristocracy.

This article contextualises classical works on feudal society, wherein land is the primary resource in almost all feudal structures. Although feudal structures have been replaced by democratic institutions in modern democracies, this paper suggests that land control and democracy might be intertwined, where political support is accumulated through the combination of land access and loyalty to traditional leaders. 


\section{References}

Amal, M. A. (2010). Kepulauan rempah-rempah: Perjalanan sejarah Maluku Utara 1250-1950. Jakarta: Kepustakaan Populer Gramedia.

Andaya, L. Y. (1993). The world of Maluku: Eastern Indonesia in the early modern period: Honolulu: University of Hawaii Press.

Anggoro, A., \& Nara, N. (2010, 14 April). Mudaffar Sjah, 35 tahun berdaulat. Kompas. Retrieved from http://internasional.kompas.com/read/2010/04/14/05331570/Mudaffar.Sjah.35.Tahu n.Berdaulat on 3 October 2015.

Aryanto, T. (2002, 3 November). Abdul Gafur: Mendagri melanggar undang-undang. Tempo. Retrieved from http://tempo.co.id/hg/nasional/2002/11/03/brk,20021103-02,id.html on 3 October 2015.

Assegaf, F. (2015). Berebut tahta Ternate. Retrieved from http://www.merdeka.com/khas/berebut-takhta-ternate-kisruh-kesultanan-ternate1.html on 3 October 2015.

Asyhari, M. (2008). Status tanah-tanah kesultanan Ternate dalam perspektif tanah nasional. Mimbar Hukum, 20(2), 193-410.

Bastin, J. S., \& Benda, H. J. (1968). A History of modern Southeast Asia: Colonialism, nationalism, and decolonization. United States: Prentice-Hall.

BPS Ternate. (2014). Ternate in numbers 2014. BPS-Ternate.

Bubandt, N. (2014). Democracy, corruption and the politics of spirits in contemporary Indonesia. London: Taylor \& Francis.

Burnet, I. (2011). Spice Islands. Australia: Rosenberg Publishing.

Christanto, D. (2009, 11 February). Court rules in favor of SBY's supporters. The Jakarta Post. Retrieved from http://www.thejakartapost.com/news/2009/02/11/court-rules-favorsby\%E2\%80\%99s-supporters.html on 6 December 2015.

Corbett, J., Veenendaal, W., \& Ugyel, L. (2016). Why monarchy persists in small states: the cases of Tonga, Bhutan and Liechtenstein. Democratization, 24(4): 689-706. DOI: $10.1080 / 13510347.2016 .1212019$

Crouch, H. (1979). Patrimonialism and military rule in Indonesia. World Politics, 31(4): 571587.

Djaafar, I. A. (2005). Dari Moloku Kie Raha hingga Negara Federal: Iskandar Muhammad Djabir Sjah: Biografi politik Sultan Ternate. Yogyakarta: Bio Pustaka.

Duncan, C. R. (2014). Violence and vengeance: Religious conflict and its aftermath in eastern Indonesia. Singapore: NUS Press.

Emmerson, D. K. (1976). Indonesia's elite: Political culture and cultural politics. Ithaca, NY: Cornell University Press. 
Firman, T. (2013). Territorial splits (Pemekaran Daerah) in decentralising Indonesia, 20002012: local development drivers or hindrance? Space and Polity, 17(2): 180-196.

Fitrani, F., Hofman, B., \& Kaiser, K. (2005). Unity in diversity? The creation of new local governments in a decentralizing Indonesia. Bulletin of Indonesian Economic Studies, 41(1): 57-79.

Gregory, A. (1976). Recruitment and factional patterns of the Indonesian political elite: guided democracy and the New Order. New York: Columbia University Press.

Hadiz, V. R. (2010). Localising power in post-authoritarian Indonesia: A Southeast Asia perspective. Redwood City, CA: Stanford University Press.

Hanna, W. A., \& Alwi, D. (1990). Turbulent times past in Ternate and Tidore. Banda Naira: Yayasan Warisan dan Budaya Banda Naira.

Huntington, S. P. (1968). Political order in changing societies. New Haven and London: Yale University Press.

Indonesian Elections Commission. (2009). Anggota DPR-RI Partai Demokrat. Retrieved from http://www.kpu.go.id/dmdocuments/Buku\%20Demokrat.pdf on 6 February 2015.

Indonesian Elections Commission. (2014). Penetapan hasil pemilu anggota DPR, DPD, DPRD provinsi dan DPRD kabupaten/kota secara nasional dalam pemilu tahun 2014 (411/Kpts/KPU/KPUTAHUN 2014). Jakarta: Indonesian Elections Commission. Retrieved from http://www.kpu.go.id/index.php/pages/detail/2014/282 on 19 April 2015.

Kabar Timur. (2014, 6 March). Keraton terus 'beringas'. Kabar-Timur.

Kasman, N. (2015, 23 March). Bobato 18 Kesultanan Ternate lengkap. Malut Post, p. 14.

Klinken, G. v. (2001). The Maluku wars: bringing society back in. Indonesia 71: 1-26. DOI: $10.2307 / 3351455$.

Klinken, G. v. (2007). Communal violence and democratization in Indonesia: Small town wars. London: Taylor \& Francis.

Kompas Research Department. (2010). Wajah DPR dan DPD 2009-2014: Latar belakang pendidikan dan karier. Jakarta: Kompas Gramedia.

Lay, C. (2001). Bulan sabit di bawah rerimbunan cengkeh: islamisasi Ternate atau Ternatenisasi Islam? In C. Lay (ed.), Agama dan Perubahan Sosial. Yogyakarta: LKPSM.

Leirissa, R. Z. (1996). Halmahera Timur dan Raja Jailolo: Pergolakan sekitar laut Seram awal abad 19. Jakarta: Balai Pustaka.

Malut Post. (2015, 20 February). Boki diboikot. Malut Post.

Marwoto, T. (2015). Gelar Permaisuri Sultan Ternate dicabut. Retrieved from http://www.antarajateng.com/detail/gelar-permaisuri-sultan-ternate-dicabut.html on 16 June 2015. 
Nurhayati, D. (2008, 11 February). Polls dispute in North Maluku faces stalemate. The Jakarta Post. Retrieved from http://www.thejakartapost.com/news/2008/02/11/polls-disputenorth-maluku-faces-stalemate.html on 16 June 2015.

Putuhena, S. (1980). Sejarah agama Islam di Ternate. In E. K. M. Masinambow (ed.), Halmahera dan Raja Ampat: Konsep dan strategi penelitian. Jakarta: Leknas-LIPI.

Sajogyo. (1970). Land and Labor in Indonesia. Unpublished paper. Sajogyo Institute.

Savirani, A. (2004). Local strongmen in new regional politics in Indonesia. Amsterdam: Master Thesis, University of Amsterdam, Amsterdam.

Selosoemardjan. (1962). Social changes in Yogyakarta. Ithaca, NY: Cornell University Press.

Seputar Malut. (2014, 4 June). Walikota Burhan (juga) digugat Sultan Mudaffar. Seputar-Malut.

Siddique, S. J. (1977). Relics of the past? A sociological study of the Sultanate of Cirebon, east Java. (PhD thesis), Universitat Bielefeld, Biefeleld.

Sidik, S. (2013). Kisruh di Kesultanan Ternate terus berlanjut. Retrieved from Okezone.com http://news.okezone.com/read/2013/09/23/340/870118/kisruh-di-kesultanan-ternateterus-berlanjut on 15 June 2015.

Smith, C. Q. (2009). The contested state and politics of elite continuity in North Maluku, Indonesia (1998-2008). Development Studies Institute, London School of Economics and Political Science: London.

Soelarto, B. (1976). Sekitar tradisi Ternate: Jakarta: Cultural Media Development Project, Directorate General of Culture, Department of Education and Culture.

Syah, H. M. (1998). Pemahaman nilai demokrasi dalam pandangan falsafah Kie Raha. Paper presented at the Penyamaan Visi/Persepsi Masyarakat Moloku Kie Raha Terhadap Daerah Tingkat I Moloku Kie Raha, Ternate.

Syah, M. (2009). Eksistensi Kasultanan Ternate dalam Sistem Tata Negara Republik Indonesia. Ternate Sultanate: Ternate.

Taib, R., Soetarto, E., \& Tonny, F. (2010). Transformasi identitas gerakan dari 'petani' menjadi 'masyarakat adat'. Transdisiplin Sosiologi, Komunikasi dan Ekologi Manusia, 4(2): 239254.

Ternate City Elections Commission. (2010). Penetapan Pasangan Calon Terpilih Walikota dan Wakil Walikota Ternate dalam Pilkada 2010. (13/KPTS/KPU-KT/IV/2010). Ternate: Ternate City Elections Commission.

Ternate City Elections Commission. (2014). 2014 Ternate City Electoral Result.

Ternate City Land Office. (2014). Pertimbangan hukum atas konflik pertanahan antara pemkot Ternate dengan Kesultanan Ternate (039/82.71/IV/2014). Ternate: Ternate City Land Office.

The Jakarta Post. (2002, 26 October). Gafur wins lawsuit against minister. The Jakarta Post.

Thorburn, C. C. (2004). The plot thickens: Land administration and policy in post-New Order Indonesia. Asia Pacific Viewpoint, 45(1): 33-49. 
Usman, D., Husain, Y., \& Saraha, S. (2014). Tahapan prosesi pengangkatan Sultan Tidore ke37 Husain Syah. Press release

Utrecht, E. (1969). Land reform in Indonesia. Bulletin of Indonesian Economic Studies, 5(3): 71 78.

Utrecht, E. (1973). Land reform and Bimas in Indonesia. Journal of Contemporary Asia, 3(2): 149.

Wilson, C. (2008). Ethno-religious violence in Indonesia: From soil to God. London: Taylor \& Francis.

Wittfogel, K. A. (1967). Oriental despotism: A comparative study of total power. New Haven: Yale University Press.

Wolters, O. W. (1970). The fall of Śrīijaya in Malay history. Ithaca, NY: Cornell University Press. 